\title{
Effects of Stocking Density and Green Water on Some Performance of European Sea Bass Fry (Dicentrarchus labrax L.) During Post - weaning Period
}

\author{
Essa, M.A' ${ }^{1}$, Omar $^{2}$, E. A., Srour ${ }^{2}$, T. M., AbdElaty ${ }^{1}$, B.S., Zahran ${ }^{1}$, S.A. \\ 1. Aquaculture Division, National Institute of Oceanography and Fisheries, Egypt \\ 2. Animal and Fish Production Dept., Faculty of Agriculture (Saba Basha), Alexandria \\ Univ., Egypt
}

\begin{abstract}
There are many problems facing the marine aquaculture in Egypt.This is due to the lack of availability of information on the care of these conditions inside the fish hatchery, which achieve higher growth rates and survival. So targeting the current study, which was conducted in NIOF Marine Hatchery, National Institute of Oceanography and Fisheries, EI-Max Research Station, Alexandria. The present study aims at evaluate the stocking densities (12 fry/aquaria \& 25 fry / aquaria) and add moss (Chlorella or Nannochloropsis) on some growth performance and benefit from food and condition factor and chemical composition of sea bass of fry has been included each transaction on the duplicates and the average weight of sea bass $D$. labrax fry $(0.48 \mathrm{~g} / \mathrm{fry})$ in the beginning where they were fed on diet containing $57 \%$ protein, with a daily average of $5 \%$ of the total live weight of the fish. The results indicated that at lower stocking density (12 fry / aquaria) in the Empty water from algae showed significantly ( $p \leq 0.05$ ) better growth performance and feed efficiency compared with water genitive algae. It may be concluded that the addition of both green water Chlorella and moss Nannochloropsis has no Influence on the performance of the fry of sea bass (Dicentrarchus labrax L.) during the postweaning period.
\end{abstract}

Key words: Dicentrarchus labrax, stocking density, green water, growth performance

\section{INTRODUCTION}

Aquaculture has attained a considerable level of production, but it is not enough to cover the demand of worldwide consumers. Hatcheries play an important role in the development of this sector as supplies of fry demand fish (Prado et al., 2010). Availability of fingerlings from the hatcheries has been one of the most critical factors for commercial success in marine fish farms. European sea bass (Dicentrarchus labrax L.) is a marine species of great economic importance, particularly in Mediterranean aquaculture. The market demand is great and as a result, the price for fresh $D$. labrax has increased markedly over the past decade due to the desirable and quality attributes of this fish. consequently, its farming is considers to be a profitable business. Egypt produces 19,027 tons of $D$. labrax (representing $1.4 \%$ of the total fish production) by catch from the Mediterranean has fluctuated between 266 tons in 1991 to 969 tons in 2011, also from north lakes about 344 tons, and D. labrax production from aquaculture sector about 17714 tons (GAFRD, 2011).Identification of environmental and management key parameters for larval rearing is important for optimizing juvenile fry production in marine fish culture (Terje et al., 2006). European Sea bass (Dicentrarchus labrax) and sea bream (Sparus aurata) are the most important teleost fish for aquaculture not only in the Mediterranean area, but also in Egypt (Farnies et al, 2001 and Essa, 2012).In Egypt, It is an economically important cultured fish species, but low level of marine fish fry rearing technology resulting in high mortality and low quality of fry (Essa, 2012).Density is one of the most deterministic factors in larvae culture, affecting social interactions such as aggressiveness, hierarchical 
phenomena and cannibalism, resulting in variations in size, survival and growth performance in fish populations (Hatziathanasiou et al., 2002). Effect of several densities on Sea bass growth, survival rate and feed conversion ratio have been tested by Santos et al.(2010) and the results showed that, increased density levels in $D$. labrax tanks reduced feed intake, survival and growth performance .

Nowadays, the life cycle of some species (sea bream, sea bass, turbot ) is under control due to important improvements in zoo technics, nutritional quality of the prey and hygienic conditions of the rearing system. Survival, growth rates and quality of the fingerlings have improved considerably during the last few years. Nevertheless, new efforts are necessary to decrease the cost per juvenile produced. Efforts should be directed towards the optimization of the rearing procedure and the variability and predictability of the results (Planas and Cunha, 1999). In general, a little information is available on the effects of sea bass fry rearing factors such as nutritional practices as green water supplementation. These mentioned factors collectively have great effect on the growth performance, water quality and subsequently affect fish production (Rotllant et al., 1997). The objective of larval rearing is to produce high-quality and healthy juvenile fish. The management of the rearing environment, stocking density and feeding regime are the most important aspects of this activity. The aim of the work, the effects of some important aspects of problems larvae culture, including the green water and stocking densities of marine sea bass post weaning larvae, on growth performance, feed utilization, survival and chemical composition parameters.

\section{MATERIALS AND METHODS}

This work was conducted through the period (June-August 2013), at Fish Rearing Laboratory, Aquaculture Division, El-Max Research Station, National Institute of Oceanography and Fisheries (NIOF), Alexandria, Egypt. This work was designed to study the effect of two stocking densities (12 fry/ aqaria\&25 fry/ aquaria) of post weaning larvae supplemented with green and normal water, on growth performance of European sea bass fry Dicentrarchus labrax.

Fish sampling: European sea bass (D. labrax) fry with an initial weight of $0.48 \pm 0.025 \mathrm{~g} /$ larvae were obtained from Marine Fish Hatchery (El Anfoshy), National Institute of Oceanography and Fisheries (NIOF), Alexandria.

Fish diet : The composition and chemical analysis of the prepared diet of $57.54 \%$ crude protein was formulated as shown in Table (1). The fry were fed five times daily at a rate of $5 \%$ of total biomass. 
Table (1): Ingredients (\%) and chemical composition (\%) of experimental diet used during the present study

\begin{tabular}{lc}
\hline \multicolumn{1}{c}{ Ingredient } & Diet \\
\hline Fish meal (70\%) & 54 \\
Corn gluten meal & 15 \\
Soybean meal & 7 \\
Wheat meddling & 6 \\
Fish oil & 9 \\
Mineral and vitamin premix & 2 \\
Vitamin C & 0.5 \\
Mono-calcium phosphate & 0.5 \\
Lysine & 2 \\
Methionine & 1 \\
Yeast extract (Diamond V XPC®) & 1 \\
Garlic extract (Garlen®) & 1 \\
Bactozyme $\AA$ & 1 \\
\hline & \\
\hline Dry matter(\% ) & 95.77 \\
Crude protein(CP) & 57.54 \\
Ether extract (E.E) & 16.30 \\
Ash\% & 14.50 \\
Crude fiber(CF) & 1.24 \\
Nitrogen free extract (NFE) & 10.42 \\
Gross energy(kcal/100g) (GE) & 494.30 \\
P/E ratio (mg CP/kcal) & 116.40 \\
\hline GE= Gross energy (kcal/100g), calculated on the basis of $5.65,4.12$ and $9.45 \mathrm{kcal}$ \\
GE/g, NFE and lipid, respectively (NRC, 1993). \\
\hline
\end{tabular}

Management: Eight glass aquaria were used during the present study in which the collected fry was distributed and acclimated in the aquaria which sized (70 $\times 30 \times 40 \mathrm{~cm}$ ) supplied with air blower system connected with fin air stone. All aquaria were filled with aerated filtered seawater $50 \mathrm{I} /$ aquaria.

The water temperature, dissolved oxygen and $\mathrm{pH}$ was measured using thermometer (YSI Professional Series Instrument, USA), salinity (Portable Refract meter operating Instructions - model GG-201/211) and total ammonia (YSI ECO Sense® 9300 photometer, England). The water quality parameters were adjusted at temperature $25 \pm 2 \mathrm{C}^{\circ}$, Dissolved Oxygen (DO) $6 \pm 1 \mathrm{mg} / \mathrm{l}$ with $90 \%-100 \%$ saturation, $\mathrm{pH} 7.9-8.2$ and salinity $30 \pm 2 \mathrm{ppt}$. The water was changed at a rate of $50 \%$ once daily.

Experimental design: In aquaria $2 \times 2$ factorial design, all fish were divided into two main groups, the first main group was included stocking density (12 fry /aquaria) and the second main group was included stocking density (25 fry / aquaria) with in each the previous two main group they were divided to other two sub groups, the first group normal seawater, the second group was, the rearing green water is seeded with microalgae such as Chlorella or Nannochloropsis.

Fry rearing: Fry rearing was performed according to Saillant et al. (2002). The water was exchanged with flow rate $50 \%$ daily. The fry were fed five times daily 
with two hours intervals at a rate of $5 \%$ body weight. The water quality parameters were monitored daily for optimum water temperature, dissolved oxygen, $\mathrm{pH}$ and salinity. The aquaria were siphoned and cleaned, then filled with clear water supplemented with green water. At $15^{\text {th }}$ day of experiment, the growth performance was evaluated each 10 days regularly until the end of experiment as the following.

\section{Evaluation of growth and feed utilization performances}

The growth performance parameters were calculated according. Total weight was determined to the nearest 0.1 milligrams (Sartorius CP224S Sartorius AG, Germany), total length was determined to the nearest mmillimeter and the fish immediately returned to their aquaria conditions and the feed amounts were adjusted and corrected according to their weight. The feed utilization parameters were determined according to Castel and Tiews (1980).

Statistical analysis: Factorial analysis $(2 \times 2)$ of the experimental treatments in triplicate result was conducted according to SPSS (version 16.00). Duncan's multiple range tests, Duncan (1955) were carried out to test the significance level among means of treatments.

\section{RESULTS AND DISCUSSION}

One of the key aspects of successful large-scale production is determining the optimum fry stocking densities. Larval and fry density studies for sea bass have not been conducted, although some work has been done on evaluating the effect of larval and juvenile densities on growth (Hatziathanasiou et al., 2002; Marte, 2003; Abdel-Rahman et al, 2003).

\section{1-Growth performance, Survival Rate and Condition factor (K) of sea bass( $D$. labrax )fry as effected by stocking density, green water treatments to reduce its effect and the is interaction}

The growth performance in weight and length of sea bass, D. labrax, under different densities with normal and green water treatments during post weaning period (70 days) are shown in Tables (2 and 3 ).

\section{1- Effect of stocking densities}

Regardless of the effect of marine water type, normal or green, in rearing experimental aquaria, the results in Table (2) indicated that, the sea bass fry reared at low density (12 fry/ aquaria) showed the highest growth performance (final body weight, total and individual daily gain, specific growth rate as well as relative growth rate) parameters compared with counterpart in the high density,( 25 fry /aquaria). The same trend was observed in the percentage of survival which achieved highest value (83.34\%) at low density conditions compared with those reared under high-density conditions (54.00\%), and the differences were significant $(\mathrm{P} \leq 0.05)$.

The results obtained for the growth performance parameters in sea bass fry length, described in Table (3), also demonstrated excellence in sea bass fry group reared in low population density compared with counterpart in the high density. The differences between two treatments were not significant evidence that the condition factor $(K)$, which is a measure of the fish health and determine 
the extent of suitable environmental conditions for the growth and living fish (Lagler,1956)-in both treatments was very tight (1.16 VS 1.18).

Concerning the effects of stocking density on growth performance of $D$. labrax, it is indicated that stocking density has been shown to have an adverse effect on growth performance and survival rate of fry during post weaning period. This might be due to the increase in stocking density results in increasing stress. This effect based on the assumption that coping with stress increases the fish's overall energy demand, which is then unavailable for growth(Leatherland and Cho 1985) reported that, in case of low stocking densities fish may not form shoals and feel comfortable. Also these findings were supported by(Irwin et al.,1999; Ma et al., 2006; Omar et al., 2006; and Essa et at., 2012 ).in other fish species who reported that, growth is inversely related to stocking density and this is mainly attributed to stress and social interactions. Negative effects of higher densities were reported also by (Salama, 2007) who found that, survival rate of Asian sea bass, Lates calcarifer $(28 \%)$ was significantly higher at a stocking density of $20 \mathrm{fry} / \mathrm{l}$, which was $2-3$ times better than at higher fry density. Also, Jodun et al. (2002).found that Atlantic sturgeon Acipenseroxy rinchus reared at the lower density had significantly higher mean weight and length at the end of the trial.

\section{2- Effect of green water and its interaction with fry stocking density}

Regardless of the effect of sea bass fry stocking density, in rearing experimental aquaria, the results in Table (2) indicated that, the sea bass fry reared under green water conditions showed the lowest growth performance (final body weight, total and individual daily gain, specific growth rate as well as relative growth rate) parameters compared with counterpart in the normal water. The same trend was observed in the percentage of survival which achieved highest value $(68.66 \%)$ at normal water conditions compared with those reared under green water conditions (62.42\%), and the differences were insignificant $(P \leq 0.05)$.

The results obtained for the growth performance parameters in sea bass fry length, described in Table (3), also demonstrated superiority in sea bass fry group reared under normal marine water conditions compared with counterpart in the green water. The differences between two treatments were not significant evidence that the condition factor $(\mathrm{K})$-which is a measure of the fish health and determine the extent of suitable environmental conditions for the growth and living fish ( Lagler,1956)-in both treatments was very tight (1.21 VS 1.13).

Concerning the effects of green water on growth performance of $D$. labrax fry, it is indicated that green water does not have an effective impact on growth performance and survival rate of fry during post weaning period. This may be due to most marine fish fry are visual feeders and feeding success of fry at various rearing period depends on the provision of suitable food, the rearing environment, and on the visibility and adequate density of the prey . Several papers have discussed the beneficial effect of adding microalgae to newly hatched marine larvae in rearing tanks in order to improve larval growth and survival These papers discuss the effect of micro-algae on the nutritional and behavioral aspects of fish larvae. Some fish larvae take up substantial amounts of micro-algae during the initial days after hatching (Van der Meeren, 1991; Reitan et al., 1993; Marte, 2003; Roca and Main, 2012) which may be used as a food source (Tamaru et al., 1994). Therefore, it can be concluded that the green 
water is important in marine newly hatched larvae more than in advanced fry. So sea bass fry in the present study achieved the best results in the case of normal marine water use.

From the results of Interactions between stocking density and green water in Tables $(2,3)$ it could be concluded that, to possess the best growth in weight and length performance parameters and survival rate for sea bass fry, $D$. labrax, under different densities with normal and green water treatments during post weaning period, taken into account the following

1-When rearing marine fish sea bass fry must use appropriate density but not high with no green water use (only normal marine water) at this stage of life, post weaning period.

2-The green water is important in marine newly hatched larvae stage more than in advanced fry.

\section{2- Feed and Nutrient utilization parameters of sea bass( $D$. labrax ) fry as effected by stocking density, green water treatments to reduce its effect and the is interaction}

The feed utilization parameters, feed intake(FI), feed conversion ratio(FCR), protein efficiency ratio(PER), protein productive value(PPV), energy retention(ER) and energy utilization(EU), of sea bass, D. labrax, under different densities with normal and green water treatments during post weaning period (70 days) are shown in Table (4) .

\section{2-1-Effect of stocking densities}

Regardless of the effect of marine water type, normal or green, in rearing experimental aquaria, the results in Table (4) indicated that, the sea bass fry reared at low density (12 fry/ aquaria) showed the best feed utilization parameters compared with counterpart in the high density, (25 fry/ aquaria) $(11.77 \mathrm{~g}, 3.28,0.55 \%, 11.21 \%, 6.57 \%$ and $11.20 \%$ vs $11.27 \mathrm{~g}, 4.54,0.39 \%$, $8.25 \%, 4.53 \%$ and $8.32 \%$, respectively). Only the differences between two treatments in ER and EU were significant $(P \leq 0.05)$.Concerning the effects of stocking density on feed utilization parameters of D. labrax, it is indicated that stocking density has been shown to have an adverse effect on feed utilization parameters of fry during post weaning period. These results are consistent with the results of superiority in growth performance of sea bass fry group reared under low-density conditions, which reflect that stocking density is considered to be a main rearing factor affecting fry growth and production in Mariculture systems. Also these findings were agreed with Bjornsson (1994), Yousif (2002) and Omar et al.(2006) who reported that, higher stocking densities, beyond the optimum levels, may lead to reduction of growth rate, increase of feed conversion ratio and lowering of survival rate.

\section{2-2- Effect of green water and its interaction with fry stocking density}

Regardless of the effect of sea bass fry stocking density, in rearing experimental aquaria, the results in Table (4) indicated that, the sea bass fry reared under green water conditions showed the worst feed utilization parameters compared with counterpart in the normal water, excluding feed intake, and the differences were significant $(P \leq 0.05)$ only in $F I$ and EU parameters. This is probably due to the above mentioned that, the green water 
Table (2): Growth performance and survival rate of sea bass( $D$. labrax )fry as effected by stocking density ,green water treatments to reduce its effect and the interaction

\begin{tabular}{|c|c|c|c|c|c|c|c|}
\hline Treatments & $\begin{array}{l}\text { Initial weight } \\
\text { (g/fish) }\end{array}$ & $\begin{array}{l}\text { Final weight } \\
\text { (g/fish) }\end{array}$ & $\begin{array}{l}\text { Weight gain } \\
\text { (g/fish) }\end{array}$ & $\begin{array}{c}\text { ADG* }^{*} \\
\text { (g/fish/day) }\end{array}$ & $\begin{array}{l}\text { SGR } \\
\text { (\%/day) }\end{array}$ & $\begin{array}{c}\operatorname{RGR}^{\star \star \star *} \\
(\%)\end{array}$ & $\begin{array}{c}\text { Survival rate } \\
(\%)\end{array}$ \\
\hline \multicolumn{8}{|c|}{ Stocking density(SD) } \\
\hline Low Density (LD) & $0.48 \pm 0.01$ & $4.20^{\mathrm{a}} \pm 0.53$ & $3.75^{\mathrm{a}} \pm 0.53$ & $0.054 a \pm 0.10$ & $3.08^{a} \pm 0.19$ & $891.62 \pm 118.94$ & $83.34^{a} \pm 2.34$ \\
\hline High Density (HD) & $0.50 \pm 0.01$ & $3.00^{\mathrm{b}} \pm 0.02$ & $2.48^{b} \pm 0.02$ & $0.035 b \pm 0.0$ & $2.52^{\mathrm{b}} \pm 0.03$ & $582.83 \pm 12.07$ & $54.00 \mathrm{~b} \pm 1.15$ \\
\hline \multicolumn{8}{|c|}{ Green water(Gw) } \\
\hline $\operatorname{Normal}(\mathrm{N})$ & $0.50 \pm 0.01$ & $4.07^{\mathrm{a}} \pm 0.62$ & $3.57^{\mathrm{a}} \pm 0.63$ & $0.051 \pm 0.01$ & $2.96 \pm 0.26$ & $835.55^{\mathrm{a}} \pm 149.95$ & $68.66 \mathrm{a} \pm 9.16$ \\
\hline Green water $(G)$ & $0.50 \pm 0.01$ & $3.15^{\mathrm{b}} \pm 0.11$ & $2.65^{\mathrm{b}} \pm 0.12$ & $0.038 \pm 0.01$ & $2.64 \pm 0.08$ & $638.900^{\mathrm{a}} \pm 35.42$ & $62.42 b \pm 5.20$ \\
\hline \multicolumn{8}{|c|}{$S D * G W$} \\
\hline$L D * N$ & $0.48 \pm 0.03$ & $5.14^{\mathrm{a}} \pm 0.03$ & $4.67^{\mathrm{a}} \pm 0.01$ & $0.067^{\mathrm{a}} \pm 0.00$ & $3.42^{\mathrm{a}} \pm 0.06$ & $1092.69^{\mathrm{ab}} \pm 49.4$ & $83.34 \pm 8.34$ \\
\hline$L D * G$ & $0.48 \pm 0.01$ & $3.30^{b} \pm 0.15$ & $2.83^{\mathrm{b}} \pm 0.15$ & $0.040^{b} \pm 0.00$ & $2.76^{\mathrm{b}} \pm 0.08$ & $690.550^{\mathrm{b}} \pm 39.61$ & $70.83 \pm 4.17$ \\
\hline$H D * N$ & $0.52 \pm 0.01$ & $3.00^{c} \pm 0.04$ & $2.48^{\mathrm{c}} \pm 0.04^{\mathrm{C}}$ & $0.035^{c} \pm 0.00$ & $2.51^{c} \pm 0.04$ & $578.405^{\mathrm{b}} \pm 14.52$ & $54.00 \pm 2.00$ \\
\hline$H D * G$ & $0.51 \pm 0.02$ & $2.99^{c} \pm 0.01$ & $2.48^{\mathrm{c}} \pm 0.03^{\mathrm{c}}$ & $0.035^{c} \pm 0.00$ & $2.52^{c} \pm 0.06$ & $587.250^{b} \pm 24.99$ & $54.00 \pm 2.00$ \\
\hline
\end{tabular}


Table (3): Condition factor (K) of sea bass ( $D$. labrax ) fry as effected by stocking density ,green water treatments to reduce its effect and the interaction

\begin{tabular}{lccc}
\hline Treatments & Initial length (cm) & Final length (cm) & Condition factor (K value) \\
\hline \multicolumn{4}{c}{ Stocking density(SD) } \\
\hline Low Density (LD) & $3.36 \pm 0.02$ & $7.15 \pm 0.36$ \\
High Density (HD) & $3.36 \pm 0.03$ & $6.33 \pm 0.04$ & $1.16 \pm 0.11$ \\
\multicolumn{4}{c}{ Green water(GW) } \\
\hline Normal water (N) & $3.36 \pm 0.02$ & $6.95 \pm 0.45$ \\
Green water (G) & $3.35 \pm 0.03$ & $6.52 \pm 0.09$ & $1.180 \pm 0.03$ \\
\hline \multicolumn{4}{c}{ SD*GW } \\
\hline LD * N & $3.33 \pm 0.00$ & $7.63 \pm 0.57$ & $1.13 \pm 0.11$ \\
LD * G & $3.40 \pm 0.00$ & $6.66 \pm 0.07$ \\
$H D * N$ & $3.40 \pm 0.00$ & $6.28 \pm 0.05$ & $1.19 \pm 0.26$ \\
$H D * G$ & $3.31 \pm 0.02$ & $6.38 \pm 0.02$ & $1.12 \pm 0.08$ \\
\hline
\end{tabular}




\section{2-2- Effect of green water and its interaction with fry stocking density}

Regardless of the effect of sea bass fry stocking density, in rearing experimental aquaria, the results in Table (4) indicated that, the sea bass fry reared under green water conditions showed the worst feed utilization parameters compared with counterpart in the normal water, excluding feed intake, and the differences were significant ( $P \leq 0.05)$ only in $F I$ and EU parameters. This is probably due to the above mentioned that, the green water is important in marine newly hatched larvae more than in advanced fry. So sea bass fry in the present study achieved the best results in the case of normal marine water use.

From the results of Interactions between stocking density and green water in Table (4) it could be concluded that, to possess the best feed utilization parameters for sea bass fry, D. labrax, under different densities with normal and green water treatments during post weaning period, taken into account the following:

1-When rearing marine fish sea bass fry must use appropriate density but not high with no green water use (only normal marine water) at this stage of life, post weaning period.

2-The differences were significant $(\mathrm{P} \leq 0.05)$ only in $\mathrm{FI}, \mathrm{ER}$ and $\mathrm{EU}$ between two treatments.

Table (4):Feed and Nutrient utilization parameters of sea bass( $D$. labrax) fry as effected by stocking density, green water treatments to reduce its effect and the interaction

\begin{tabular}{lccccc}
\hline \multicolumn{1}{c}{ Treatments } & $\begin{array}{c}\text { Feed take } \\
\text { (g/fish) }\end{array}$ & FCR & $\begin{array}{c}\text { PER } \\
(\%)\end{array}$ & $\begin{array}{c}\text { PPV } \\
(\%)\end{array}$ & $\begin{array}{c}\text { EU } \\
(\%)\end{array}$ \\
\hline \multicolumn{5}{c}{ Stocking Density(SD) } \\
\hline Low density (LD) & $11.77 \pm 0.75$ & $3.28 \pm 0.38$ & $0.55 \pm 0.06$ & $11.21 \pm 1.29$ & $11.2 \pm 1.51$ \\
High density (HD) & $11.27 \pm 0.96$ & $4.54 \pm 0.39$ & $0.39 \pm 0.03$ & $8.25 \pm 0.86$ & $8.32 \pm 0.73$ \\
\hline \multicolumn{5}{c}{ Green water(GW) } \\
\hline Normal (N) & $11.05 \pm 0.84$ & $3.27 \pm 0.35$ & $0.55 \pm 0.06$ & $11.51 \pm 1.11$ & $11.62 \pm 1.25$ \\
Green water (G) & $11.98 \pm 0.83$ & $3.55 \pm 0.41$ & $0.39 \pm 0.04$ & $7.95 \pm 0.72$ & $7.89 \pm 0.55$ \\
\hline \multicolumn{5}{c}{ SD GW } \\
\hline D $^{*} N$ & $11.51 \pm 0.00^{\mathrm{a}}$ & $1.67 \pm 0.01$ & $0.65 \pm 0.00$ & $13.4 \pm 0.10$ & $13.74 \pm 0.22^{\mathrm{a}}$ \\
$\mathrm{LD}^{*} \mathrm{G}$ & $11.03 \pm 1.5^{\mathrm{b}}$ & $2.88 \pm 0.34$ & $0.45 \pm 0.04$ & $9.03 \pm 0.77$ & $8.64 \pm 0.75^{\mathrm{c}}$ \\
$\mathrm{HD}{ }^{*} \mathrm{~N}$ & $9.60 \pm 0.00^{\mathrm{b}}$ & $2.87 \pm 0.07$ & $0.45 \pm 0.01$ & $9.64 \pm 0.65$ & $9.49 \pm 0.55^{\mathrm{b}}$ \\
HD *G & $12.92 \pm 0.00^{\mathrm{a}}$ & $3.21 \pm 0.06$ & $0.33 \pm 0.01$ & $6.86 \pm 0.35$ & $7.14 \pm 0.39^{\mathrm{c}}$ \\
\hline
\end{tabular}

* Feed conversion ratio (FCR) - Protein efficiency ratio (PER) - Protein productive value (PPV \%) - Energy utilization (EU) 
3- Chemical composition parameters of sea bass (D. labrax) fry as effected by stocking density, green water treatments to reduce its effect and the is interaction

\section{3-1 Effect of stocking densities}

Regardless of the effect of marine water type, normal or green, in rearing experimental aquaria, the results in Table (5) indicated that, the sea bass fry reared at low density (12fry / aquaria) showed the best chemical composition parameters compared with counterpart in the high density,( 25fry/ aquaria) (28.78, 62.31, 19.01, 18.53 and 530.88 vs 28.92, 60.18, 19.48, 20.40 and 523.36 for dry matter, crude protein, ether extract, ash and gross energy, respectively).Only the differences between two treatments in ether extract, ash and gross energy were significant $(P \leq 0.05)$. These results are consistent with the results of growth and feed utilization.

\section{3-2 Effect of green water and its interaction with fry stocking density}

Regardless of the effect of sea bass fry stocking density, in rearing experimental aquaria, the results in Table (5) indicated that, the sea bass fry reared under normal marine water conditions showed the best chemical composition parameters compared with counterpart in the green water, and the differences were significant $(P \leq 0.05)$ only in ether extract, ash and gross energy content. This is probably due to the above mentioned that, the green water is important in marine newly hatched larvae more than in advanced fry. So sea bass fry in the present study achieved the best results in the case of normal marine water use.

From the results of Interactions between stocking density and green water in table (5) it could be concluded that, to possess the best chemical composition parameters for sea bass fry, $D$. labrax, under different densities with normal and green water treatments during post weaning period, taken into account the following:

1-When rearing marine fish sea bass fry must use appropriate density but not high with no green water use (only normal marine water) at this stage of life, post weaning period.

2-The differences were significant $(P \leq 0.05)$ only in ether extract, ash and gross energy content between two treatments. 
Table (5): Chemical composition parameters of sea bass (D. labrax) fry as effected by stocking density, green water treatments to reduce its effect and the is interaction

\begin{tabular}{|c|c|c|c|c|c|}
\hline Treatments & $\begin{array}{l}\text { Dry matter } \\
\text { (\%) }\end{array}$ & $\begin{array}{c}\text { Crude protein } \\
(\%)\end{array}$ & $\begin{array}{c}\text { Ether extract } \\
(\%)\end{array}$ & $\begin{array}{l}\text { Ash } \\
(\%)\end{array}$ & $\begin{array}{l}\text { Energy content } \\
(\mathrm{kcal} / 100 \mathrm{~g})\end{array}$ \\
\hline Initial & $27.76 \pm 0.23$ & $53.65 \pm 0.21$ & $15.68 \pm 0.54$ & $21.54 \pm 0.02$ & $504.33 \pm 045$ \\
\hline \multicolumn{6}{|c|}{ Stoking Density(SD) } \\
\hline Low-density (LD) & $28.78 \pm 0.63$ & $62.31 \pm 0.41$ & $19.01 \pm 1.29$ & $18.53 \pm 1.73$ & $530.88 \pm 0.47$ \\
\hline High-Density (HD) & $28.92 \pm 0.82$ & $60.18 \pm 0.86$ & $19.48 \pm 0.64$ & $20.40 \pm 0.24$ & $523.36 \pm 0.45$ \\
\hline \multicolumn{6}{|c|}{ green water(GW) } \\
\hline Normal (N) & $29.26 \pm 0.68$ & $62.29 \pm 0.43$ & $19.84 \pm 0.84$ & $18.12 \pm 1.48$ & $538.60 \pm 0.22$ \\
\hline Green Water(G) & $28.44 \pm 0.70$ & $60.19 \pm 0.86$ & $18.65 \pm 1.08$ & $20.86 \pm 0.42$ & $515.64 \pm 0.30$ \\
\hline \multicolumn{6}{|c|}{ SD*GW } \\
\hline$L D * N$ & $29.76 \pm 0.56$ & $62.95 \pm 0.37$ & $21.2^{a} \pm 0.42$ & $15.55^{\mathrm{c}} \pm 0.11$ & $555.41^{a} \pm 0.05$ \\
\hline$L D * G$ & $27.81 \pm 0.40$ & $61.66 \pm 0.24$ & $16.80^{\mathrm{c}} \pm 0.11$ & $21.52^{\mathrm{a}} \pm 0.09$ & $506.36^{\mathrm{c}} \pm 0.11$ \\
\hline$H D * N$ & $28.76 \pm 1.42$ & $61.64 \pm 0.34$ & $18.4^{b} \pm 0.43$ & $20.67^{\mathrm{b}} \pm 0.24$ & $521.79^{b} \pm 0.42$ \\
\hline$H D * G$ & $29.07 \pm 1.40$ & $58.74 \pm 0.38$ & $20.5^{a} \pm 0.34$ & $20.22^{\mathrm{b}} \pm 0.43$ & $524.93^{b} \pm 0.43$ \\
\hline
\end{tabular}

\section{CONCLUSION}

From the results of the present study we can concluded that showed mostly better growth performance, feed utilization and survival in lower stocking density (12fry / aquaria) than higher stocking density(25fry/ aquaria). It may be concluded that the addition of both green water, Chlorella or Nannochloropsis has no effect on the performance of the fry of sea bass during the post-weaning

\section{ACKNOWLEDGEMENT:}

The authors gratefully acknowledge all staff of fish breeding and rearing lab, NIOF; Alexandria, for their help and supporting during the experiment period.

\section{REFERENCES}

Abdel- Rahman, S.H. F.H. Farrage. M.A. Essa and A.M. Helal. 2003. Rearing and advanced fry of sea bass (Dicentrarchus labrax) in tanks at different stocking density and culture methods. J. Agricultural. Sci., Mansoura Univ., 28 (2): 851-861.

Bjornsson, B. 1994. Effects of stocking density on growth rate of Halibut Hippoglossu shippoglossusL. Reared in large circular tanks for three years. Aquaculture, 123: 259-270.

Castel, J.D. and Tiewes, K. 1980. Report of the EIFAC, IUNS and ICES Working Group on Standardization of Methodology in Fish Research. Hamburg, FRQ, 21 - 23 March 1979. IFAC Tech.Pap. (3): 24. 
Duncan, D. B.1955. Multiple ranges and multiple F test. Biometric, 11:1-42.

Essa, M.A. 2012.The current situation of aquaculture in Egypt achievements, problems and obstacles to development. Force WP2 Training Cours"Indicators and Simulation models for site selection and EIA of finfish mariculture"Alexandria, $8^{\text {th }}$ to $11^{\text {th }}$ October 2012, NIO.

Essa, M.A., Omar, E.A., Srour, T.M., Helal, A.M. and Elokaby, M.A. 2012. Effect of stocking density on growth performance, feed utilization, production and economic feasibility of thin lip grey mullet (Liza ramada) fingerlings, reared in floating net cages at the end of River Nile of Egypt. J. Applied Agricultural Research, Vol.17 (1): 105 - 121.

Farnies, M.A., Manaucs, E. and Carrillo, M. 2001. Spawning induction of European sea bass females using different $\mathrm{GnRHa}$ - delivery systems. Aquaculture, 202: $221-234$.

GAFRD. 2011. Fish catch and aquaculture statistics in 2011 from General Authority for Fish Resources Development.

Hatziathanasiou, A., Paspatis,M., Houbart, M., Kestemont, P., Stefanakis,S.,Kentouri, M. 2002.Survival, growth and feeding in early life stages of European sea bass(Dicentrarchus labrax) intensively cultured under different stocking densities. Aquaculture, 205(1-2):89-102.

Irwin S., Halloran J. O., FitzGerald R., D. 1999.Stocking density, growth and growth variation in juvenile turbot, Scophthalmusmaximus (Rafinesque). Aquaculture, 178(1-2):77-88.

Jodun,W.A., Millard, M.J., and Mohler, J. 2002. The effect of rearing density on growth, survival, and feed conversion of juvenile Atlantic sturgeon. North American Journal of Aquaculture, 64: 10-15.

Lagler, K.F. 1956. Fresh water fishery biology. Wm.C. Brown Company, Dubuque, 1A. pp. $131-166$.

Leatherland, J.F. and Cho, C.Y. 1985.Effect of rearing density on thyroid and nterregnal gland activity and plasma and hepatic metabolite levels in rainbow trout, SalmogairdneriRichardson. Journal of Fish Biology, 27: 583592.

Ma, A., Chen, C., Lei, J., Chen, S., Zhuang, Z. and Wang, Y. 2006. Turbot Scophthalmusmaximus: stocking density on growth, pigmentation and feed conversion. (Abstract) Chinese J. of Oceanology and Limnology, 24(3): 307-312.

Marte, C. L. 2003.Larva culture of marine species in Southeast Asia. Aquaculture, 227: $293-30$.

NRC. 1993. Nutrient Requirements of workmates fishes and shell fishes, National Research Council, rev.ed., National Academy Press, Washington, DC,USA.

Omar, E., Nour, A .M., Essa, M.A., Zaki, M.A. and Mabrouk, H.A. 2006.Technical and economical evaluation of small scale cage culture for youth in the River Nile of Egypt: 1- Effect of stocking density of Nile tilapia monosex. 2ndIntern.Conf- In Fish Cage Culture in Asia, Hangzhou, Zhejiang Province, China, from 3-8 July, 2006.

Planas, M.and Cunha.1999. Larval culture of marine fish: Problems and prospective. Aquaculture,177, (1 - 4) : 171 - 190.

Prado, J., Carp, J., Weissman, D.H. 2010. Variations of response time in a selective attention task are linked to variations of functional connectivity in the attentional network. Neuroimage, 54: 542-550. 
Reitan, K.I., Rainuzzo, J.R., Pie, G., Olsen, Y. 1993. Nutritional effects of algal addition in first-feeding of turbot (Scophthalmusmaximus L.) larvae. Aquaculture, 118: 257-275.

Roca, C. Y. and Main. K. L.2012. Improving Larval Culture and Rearing Techniques on Common Snook (Centropomusundecimalis), Aquaculture, Dr.ZainalMuchlisin(Ed.),ISBN:9789533079745,InTech,Availablefrom:http:// www.intechopen.com/books/aquaculture/improving-larval-culture-andrearingtechniques-on-common-nook-centropomus-undecimalis

Rotllant, J., Pavlidis, M., Kentouri, M., Abad, M.E. and Tort, L. 1997.Nonspecific immune responses in the red porgy Pagruspagrusafter crowding stress. Aquaculture, 156: 279-290.

Saillant, E., Fostier, A., Haffray, P., Menu, B., Thimonier, J., Laureau, S., Chatain,B. 2002.Temperature effects and genotype temperature interactions on sex determination in the European sea bass (Dicentrarchus labra L.).J. Exp. Zool. 292, 494-505.

Salama, A.J. 2007. Effects of stocking density on fry survival and growth of Asian sea bass, lates calcarifer. JKAU: Mar. Sci., 18: 53-61.

Santos, G.A., Schrama, J.W., Mamauag, R.E.P., Rombout, J.H.W.M. and Verreth, J.A.J. 2010. Chronic stress impairs performance, energy metabolism and welfare indicators in European sea bass (Dicentrarchus labrax): The combined effects of fish crowding and water quality deterioration. Aquaculture, 299: 73-80.

Tamaru, C.S., Murashige, R., Lee, C. 1994.The paradox of using background phytoplankton during the larval culture of striped mullet, Mugil cephalusL Aquaculture, 119:167-174.

Terje van der Meerena, Anders Mangor-Jensena, Jana Pickovab. 2006. The effect of green water and light intensity on survival, growth and lipid composition in Atlantic cod (Gadusmorhua) during intensive larval rearing. Institute of Marine Research, Austevoll Research Station, NO-5392 Storebø, NorwaybSwedish University of Agricultural Sciences, Dep. Of Food Science, P.O.Box 7051, 75007 Uppsala, Sweden

Van der Meeren, T. 1991. Algae as first food for cod larvae, Gadusmorhua L.: filter feeding or ingestion by accident? J. Fish Biol. 39, 225-237.

Yousif, O.M. 2002. The effects of stocking density, water exchange rate, feeding frequency and grading on size hierarchy development in juvenile Nile tilapia, Oreochromis niloticusL. Emir. J. Agricultural. Sci., 14: 45-53. 
الملخص العربي

\title{
تأثير الكثافة العددية والمياه الخضراء على بعض معايير الأداء ليرقات أسماك القاروص البحرية أثناء مرحلة ما بعد الفطام
}

\author{
محمد عبد الرازق عيسى 1ـاجبلال على عمر ${ }^{2}{ }^{2}$ \\ باسم سعد عبد العاطى 1 - سيد احمد عبدالتبي زهران 1 \\ 1- المعهد القومى لعلوم البحار والمصايد - شعبة تربية الاحياء المائية - الأسكندرية \\ 2- قسم الإنتاج الحيوانى والسمكى - كلية الزراعة (سابا باشا) - جامعة الأسكندرية
}

هناك العديد من المشاكل التى تواجه الإستزراع السمكى البحرى فى مصر هذا يرجع الى عدم وفرة المعلومات عن

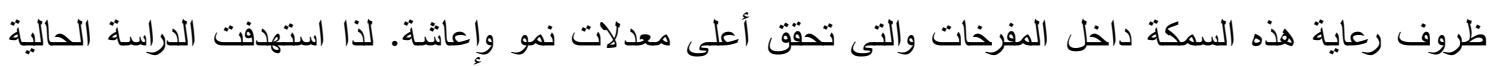
والتى أجريت بالمفرخ السمى البحرى لمدة 70 يوم بمحطة بحوث المكس التابعة للمعهد القومي لعلوم البحار والمصايد-فرع الاسكندرية ليرقات أسماك القاروص بهدف ثأثثر الكثافة العددية لكثافتين مختلفتنين (12 برقة /حوض\& 25يرقة / حوض) وإضافة طحلب (كلوريلا \& نانوكلوربس) علي بعض معايير النمو والإستفادة من الغذاء ومعامل الحاله والتركيب الكيماوى ليرقات أسماك القاروص وضد وضد شملت كل معاملة على مكررتين وكان منوسط وزن يرقات القاروص ( 0.48 جرام/ يرقة ) فى البداية حيث تم تغذيتها على عليقة تحتوي على 57 5

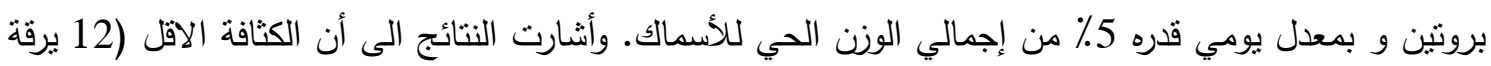

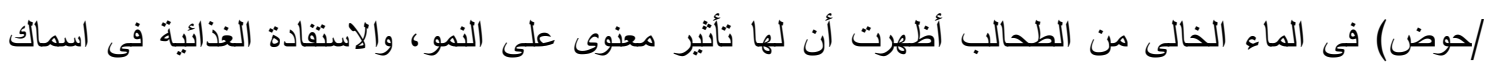

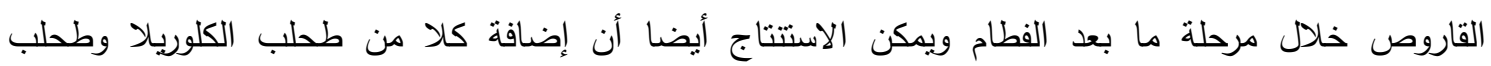

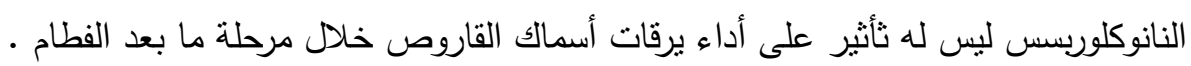

